\title{
CORRIGENDUM
}

\section{Corrigendum: Breakthroughs in hereditary angioedema management: a systematic review of approved drugs and those under research}

\section{Abstract}

The authors wish to make corrections to their article:
Nicola S, Rolla G, Brussino L. Breakthroughs in hereditary angioedema management: a systematic review of approved drugs and those under research. Drugs in Context 2019; 8: 212605. DOI: $10.7573 /$ dic. 212605

\section{Corrigendum}

The authors regret that there are errors in their original paper.

1. The following shows where original text has been removed (strikethrough) and new wording introduced (underlined).

\section{Page 3, section on Berinert ${ }^{\circledast}$}

In 2009, the US FDA approved Berinert ${ }^{\circledR}$ (CSL Behring), a pasteurized plasma-derived C1-INH concentrate, available for intravenous (IV) administration in patients needing ondemand therapy. This drug was also not approved for shortterm prophylaxis in the EU in 2013. but is used off-label for this purpose.

The following reference from the Head of Medicine website (EU approval document) should also be added to this statement:
https://mri.cts-mrp.eu/Human/Downloads/DE_H_0481_003_ PAR.pdf

\section{Page 5 , section on Haegarda ${ }^{\circledast}$}

\section{C1-INH (SC) Haegarda ${ }^{\circledR}$}

Haegarda $^{\circledR}$ and Berinert ${ }^{\circledR}$ 2000/3000 (CSL Behring) were approved (US and EU) was approved by the FDA in 2017 as the first subcutaneous $\mathrm{C} 1$ inhibitor concentrate, also indicated for self-administration, at the dose of $60 \mathrm{IU} / \mathrm{kg}$ twice weekly. Nevertheless, the European Medicines Agency did not formally approve the marketing of the drug. ${ }^{29}$

2. Table 1 lists two products Berinert ${ }^{\oplus}$ and Haegarda ${ }^{\circledast}$ on separate lines; however, they should be grouped together as follows:

\begin{tabular}{|c|c|c|c|c|c|}
\hline Drug name & $\begin{array}{l}\text { Active } \\
\text { substance }\end{array}$ & Type and action & Administration & Indication & $\mathrm{T} 1 / 2$ \\
\hline Berinert $^{\oplus}$, CSL Behring & C1-INH & $\begin{array}{l}\text { Plasma-derived C1-INH } \\
\text { concentrate pasteurized, } \\
\text { nanofiltered }\end{array}$ & IV & $\begin{array}{l}\text { On-demand, } \\
\text { short-term } \\
\text { prophylaxis }\end{array}$ & $36-48$ hours \\
\hline $\begin{array}{l}\text { Berinert }^{\circledast} 2000 / 3000 \\
\text { (Haegarda }^{\oplus} \text { brand } \\
\text { name in the United } \\
\text { States and Canada) }\end{array}$ & C1-INH & $\begin{array}{l}\text { Plasma-derived C1-INH } \\
\text { concentrate pasteurized, } \\
\text { nanofiltered }\end{array}$ & SC & $\begin{array}{l}\text { Long-term } \\
\text { prophylaxis }\end{array}$ & 69 hours \\
\hline
\end{tabular}

